\title{
Stock Market Performance under Different Government Periods: Evidence from Bangladesh
}

\author{
Md. Afzalur Rahaman ${ }^{1}$, Md. Bokhtiar Hasan ${ }^{1, *}$, A. F. M. Mainul Ahsan ${ }^{2}$ \\ ${ }^{1}$ Research, Development \& Information Department, Dhaka Stock Exchange, 9/F Motijheel, Dhaka, Bangladesh \\ ${ }^{2}$ Department of Economics, School of Business, Independent University, Bangladesh (IUB), Dhaka-1229, Bangladesh \\ *Corresponding Author: bokhtiar_bank@yahoo.com
}

Copyright $@ 2013$ Horizon Research Publishing All rights reserved.

\begin{abstract}
While there are many factors that influence stock market activity, the main focus of this paper is to examine stock market performance under different political leadership in Bangladesh. This study mainly considers two different daily DSE indices' (DSI and DGEN) return and some key market indicators for the sample period March 20, 1991 to April 30, 2013. We basically analyzed average market return, volatility and risk for each government term (five terms) individually. By means of descriptive observation and statistical analysis we found evidence that the performance of stock market was superior under government term 4 (2006 to 2009) while performance was worst under government term 2 (1996 to 2001) and term 5 (2009 to 2013). It was also found that the government term 4 was led by nonpolitical party, i.e. Caretaker government whereas the government terms $2 \& 5$ were led by the same political party.
\end{abstract}

Keywords Return, Volatility, Democracy, Political, Dhaka Stock Exchange, Performance

\section{Introduction}

The people of Bangladesh discovered their identity through the Language Movement in 1952. The struggle to establish their identity and national spirit began soon after 1947 when they realized that under Pakistan created on the two nation theory there was little scope for the distance culture of Bangladeshis to flourish. Thus Bangladesh plunged into a civil war. During the nine months struggle which ensued an estimated three million Bengalis died and ten million refugees fled into neighboring countries. On December 16, 1971, the Bangladesh emerged as an independent and sovereign country in the world. The new state, the People's Republic of Bangladesh was founded as a constitutional, secular, democratic, multi-party, parliamentary republic. After independence to year 1991, four general elections were held in 1973, 1979, 1980 and
1988 in Bangladesh (Bijon, 2012). But most of the time Bangladesh endured political turmoil and military coups. However, to avoid such type of political turmoil and military coups, Bangladesh spread no stone unturned. After all these efforts, a caretaker government was first introduced in 1990. Since then, the Caretaker government held the elections in Bangladesh. This can be recognized as the restoration of democracy in Bangladesh.

It is called that Bangladesh has an endless possibilities to become a developed country within the shortest period of time. But, since independence, it continues to face a number of major challenges, including political and bureaucratic corruption and political instability. Since 1991, our two main parties: Bangladesh Nationalist Party (BNP) and Bangladesh Awami League (AL), come on the power one after another. But both parties always tried to discontinue the previous Government policies. In addition, massive anomalies, corruption and political unrest were seen in all terms of the Government while the economic development was always ignored. It is thought that this bad politics always strike our stock market harshly which resulted several turmoil in 1990, 1996, 2011 and 2012 for instance. Stock market is a very sensitive market and confidence among investors is the main thing. Political instability and unrest obviously destroy confidence among investors on the stock market.

Table 1. Details of Sample Government periods

\begin{tabular}{|c|c|}
\hline \multicolumn{2}{|c|}{ Details of Sample Government periods } \\
\hline Political Parties & Ruling Periods \\
\hline Government Term 1 & 1991 to 1996 \\
\hline Government Term 2 & 1996 to 2001 \\
\hline Government Term 3 & 2001 to 2006 \\
\hline Government Term 4 & 2006 to 2009 \\
\hline Government Term 5 & 2009 to 2013 (continue) \\
\hline
\end{tabular}

Whenever our stock market goes turmoil, all keep accusing Government. They make a particular Government responsible for all the chaos in stock market. Although this blame has no base as any formal research was conducted yet regarding this issue in Bangladesh, but government cannot 
ignore the liability for any turmoil in the market during their regime. Hence, we inspired to conduct this study. This study mainly investigates the performance of stock market under different Government periods in Bangladesh since 1991 to 2013. Our sample period covers four political Government terms: 1991 to 1996, 1996 to 2001, 2001 to 2006 and 2009 to 2013, including one nonpolitical Government; Caretaker (2006 to 2009). Table 1 details the sample Government periods.

We performed two analyses: descriptive and statistical analysis. For descriptive analysis we used turnover, market capitalization, market capitalization to GDP ratio, index, IPO, turnover ratio, and average daily value traded. For descriptive statistical analysis: we used market return (through "DSI" and "DGEN" index). Here, stock market means Dhaka stock exchange only as it is the main bourse of Bangladesh. From both the analyses, we found that the government term 4 (2006 to 2009) was the best for stock market performance where the market experienced comparatively less volatility along with highest average return. On the other hand, the government term 2 (1996 to 2001) and term 5 (2009 to 2013) were the worst for stock market performance with high volatility against very low or negative average return and most of the market indicators showed very low or negative growth.

The rest of the paper is therefore organized as follows. Part 2 will discuss the literature review regarding this issue. Part 3 will brief about the Dhaka stock exchange. Part 4 will focus on Methodology and data. Part 5 will analyze the result of this research. Part 6 will conclude the study.

\section{Literature Review}

The performance of the stock market is influenced by a number of factors, the main ones among them being the activities of governments and the general performance of the economy. Extensive studies have been carried out in America and Britain examining the performance of stock markets before and after general elections. They have also examined the performance of the stock markets based on the party of the President or Prime Minister in Power. These studies indicate that the stock market react differently based on the party of the President elected in America while there was no difference in Britain. On the other hand, we did not find any research linking different Government terms with stock market performance in Bangladesh. We, first time, are going to conduct such study in Bangladesh. Now we will discuss some major works related to our study.

Relationship between presidency and stock market has shown very prudently by Ray and Marshall (2012). They focused on the relationship between U.S. political parties holding presidential office and S\&P 500 performance, volatility, and risk. The research was encompassed the specific years within presidential cycle were evaluated for price change over time and observations were made to determine if there were any relationships between the political party in office and historical stock market performance. They described through Descriptive observations that the average S\&P 500 nominal returns shows 55.03 percent and 23.48 percent for the two different government period in USA for the period of January 20, 1949 to projected January 20, 2013. To minimize the argument regarding inflation, they made further adjustments using the Consumer Price Index chain with a base year of 1980 equal to 100 . The results were more modest. They also found that, while the descriptive observations would suggest some difference between the political parties holding the presidency and the performance of the S\&P 500, there was no significant statistical difference between the political party that holds the government and S\&P 500 performance at the 95 percent level of confidence both in the nominal as well as in the adjusted composite price levels.

Applying conditional volatility models, Roland and Michael (2007) analyzed the impact of expected government partisanship on stock market performance in the 2002 German federal election. Their results showed that small-firm stock returns were positively (negatively) linked to the probability of a right- (left-) leaning coalition winning the election. Moreover, they found that volatility increased as the electoral prospects of right-leaning parties improved, while greater electoral uncertainty had a volatility-reducing effect.

Jedrzej, Katrin and Tomasz (2006) performed an analysis of 24 stock markets and 173 different governments and found that there are no statistically significant differences in returns between left-wing and right-wing executives. Consequently, international investment strategies based on the political orientation of countries' leadership are likely to be futile.

Oumar and Ashraf (2011) examined the link between stock returns and the presidential cycle in the United States. They investigated whether there is a risk-based explanation for higher returns during Democratic presidencies compared with Republican presidencies. The findings show that the market exhibits higher returns when Democrats control the presidency, with smaller companies experiencing the most significant improvement.

Santa-Clara and Valkanov (2003) found that there was a higher excess return in the stock market (using a stock market index compared to three-month Treasury Bill) when Democrats were in office. According to their research, which does not include the last two presidential terms, the excess returns were 09 percent for the value weighted stock indexes and 16 percent for the equal weighted portfolio.

Beyer, Jensen, and Johnson (2004) showed that political gridlock as well as monetary expansion and restrictive fiscal policies had effects on security performance. They concluded that the evidence is contrary to popular opinion that the stock market benefits from political gridlock. After controlling for shifts in the political landscape, they found strong evidence that shifts in Fed policy have a significant relationship with the security returns.

Nikhar (2013) used the surprise, positive jolt that Osama 
Bin Laden's capture gave to Barack Obama's 2012 re-election prospects to study the relationship between business campaign contributions, political connections, and stock market valuation changes. He found that following Bin Laden's death, firms that had previously donated to Democrats registered significant positive returns whereas firms that had donated to Republicans registered significant negative returns. His findings indicate that campaign contributions serve as financial investments that can yield major valuation payoffs to firms because investors view these as signals of political connections.

Ansolabehere, Snyder Jr. and Ueda (2004) found that these rulings appear to have had no noticeable effect on the stock prices of firms that were directly affected leading the authors to conclude that the fundamental critique of campaign finance in America-that donations come with a quid pro quo and extract very high returns for donors-is almost surely wrong.

\section{The Dhaka Stock Exchange (DSE): a Brief Description}

In early 1952, five years after the independence of Pakistan, the Calcutta Stock Exchange prohibited transactions in Pakistani stocks. This necessitated the formation of a stock exchange in East Pakistan. Eventually, on 28 April 1954 the East Pakistan Stock Exchange Association Ltd. was incorporated. However, formal trading began in 1956 with 196 securities listed on the DSE with a total paid up capital of about Taka 4 billion (Chowdhury, 1994). It changed its name to East Pakistan Stock Exchange Ltd on 23 June 1962 and finally to Dhaka Stock Exchange (DSE) on 14 May, 1964.

After 1971, the trading activities of the Stock Exchange remained suspended until 1976 due to the liberation war. The trading activities resumed in 1976 with only 9 companies listed having a paid up capital of Taka 137.52 million on the stock exchange (Chowdhury, 1994).

There are 250 members and total 522 listed securities in Dhaka Stock Exchange till May 30, 2013. The working days of DSE is 5 days in a week without Saturday, Sunday public holidays \& other government holidays. The trading time is from 10:30 am to $2: 30 \mathrm{pm}$ (local time). Investment options for an investor in this market are ordinary share, Debenture, Bond \& Mutual funds.

In the beginning, DSE was a physical stock exchange and used to trade in the open out-cry system. After that to secure smooth, timeliness \& effective operation on the market, DSE uses automated trading system. The system was installed on 10th August, 1998 and was upgraded time to time. The latest up-gradation was web based trading software-MSA Plus which is introduced on June 10, 2012. Now, investors are able to submit buy/sale orders on Dhaka stock exchange from anywhere of the world through Internet.

Before January 28, 2013, DSE had three indices, DSI (All share), DGEN (A, B, G \& N) and DSE 20 where DGEN was treated as benchmark. None of the DSE indices include mutual funds, bonds and debentures. However, on January 28, 2013 DSE introduced two new indices which are known as the DSE Broad Index (DSEX) and DSE 30 Index (DS30) based on free float and S\&P methodology. Now, DSEX is considered as benchmark index in DSE.

\section{Methodology and Data}

For our present study we have basically performed two analyses:

1) Descriptive observations and

2) Descriptive statistical analysis

Applying these two analyses we mainly evaluated the market return, volatility and risk of the stock market at each government period individually since 1991. We also observed whether the political parties holding power in government had any statistical influence on stock market performance.

For the descriptive analysis, we used some key indicators of stock market, i.e. turnover, market capitalization, market capitalization to GDP ratio, index, IPO, turnover ratio, and average daily value traded. Here, we observed the growth pattern of these indicators. Descriptive analysis also includes graphical presentation where we showed daily index and turnover.

Here,

Turnover ratio $(\%)=$ Total turnover/ Market capitalization * 100

Average daily value traded $=$ Total turnover $/$ number of trading days

Market capitalization to GDP ratio = Market capitalization / GDP * 100

For descriptive statistical analysis, we used daily index return as market return (through "DSI" and "DGEN" index). DSI index includes all stocks where DGEN index includes all stocks except $Z$ category firms. The daily index return in period $t$ is calculated using the simple return formula,

Where,

$$
R_{t}=\frac{P_{t}-P_{t-1}}{P_{t-1}}
$$

$\mathrm{P}_{\mathrm{t}}=$ Value of security DSI / DGEN Index on day $\mathrm{t}$ and

$\mathrm{P}_{\mathrm{t}-1}=$ Value of security DSI / DGEN Index on day prior to day $\mathrm{t}$

Our sample data covers the period from March 20, 1991 to April 30, 2013. This sample period is also divided into five different government terms: Term 1 (March 20, 1991 to March 19, 1996), Term 2 (June 23, 1996 to July 15, 2001), Term 3 (October 10, 2001 to October 22, 2006), Term 4 (October 31, 2006 to January 05, 2009) and Term 5 (January 05, 2009 to April 30, 2013). The last term of government is not completed yet. 
Since, before November 27, 2001 DSE had only one index, DSE all share Price Index (DSI) and the DSE General Index (DGEN) was introduced on November 27, 2001, for all analyses, we used DSI index for the first two government terms ('1991 to 1996' and '1996 to 2001') and used DGEN for the rest of the three terms ('2001 to 2006', '2006 to 2009' and '2009 to 2013'). But, before January 01, 1995, daily turnover is not available, only monthly turnover is available. Therefore, for the first government term (1991 to 1996), graphical presentation starts from January 01, 1995.

All data related to stock market are collected from DSE official website; www.dsebd.org and DSE library. GDP data are collected from Bangladesh bank official website; www.bangladesh-bank.org. For all the statistical computation, we used Microsoft Excel and its data analysis tool.

\section{Data Analysis and Result}

This section has two parts. In first part, we just described the results obtained from both the descriptive and statistical analyses for each government term separately. The second part includes major findings where we performed comparative analysis among different government terms.

\section{Government Term 1 (1991 to 1996)}

Descriptive Observations: In table 2; on March 20, 1991 the aggregated value of all trading deals that measures the efficiency and intensity of assets allocation was Tk. 0.37 million, which stood at Tk. 29.50 million on March 19, 1996 representing 7856 percent growth. The total value of a stock exchange; Market Capitalization was Tk. 11.90 billion on March 20, 1991, which reached at Tk. 52.44 billion on March 19, 1996 registering 341 percent growth. DSE All Share Index (DSI) was 351.00 points on March 20, 1991 which increased to 830.69 points on March 19, 1996 confirming 137 percent up. The average daily value traded was Tk. 9.46 million during this period which was Tk. 0.54 million in previous term of the government demonstrates 1657 percent appreciation. Market Capitalization to GDP ratio was 3.15 on March 19, 1996. At the beginning of the term, the turnover ratio was 0.003 percent, that increased by 1706 percent to 0.056 percent. During the tenure, a total 67 firms have off-loaded shares in the capital market.

Chart 1 shows the daily DSI index and turnover value. The highest daily turnover value and DSI Index were Tk. 141.01 million and 903.04 points respectively whereas the lowest turnover and DSI Index were Tk. 3.62 million and 284.37 points respectively during this term.

Statistical Analysis: In table 7, total 1337 observations have been used in statistical analysis for this government term. In statistical findings based on the DSI Index return, the expected value or average mean return was 0.075 percent. It is the mean value of returns that investors try to maximize at each level of risk. The median return was 0.014 percent. The Standard deviation and coefficient of variation (CV) were 1.63 percent and 21.59 respectively.

Table 2. Government TERM-1 (1991 to 1996)

\begin{tabular}{|l|r|r|r|}
\hline \multicolumn{4}{|c|}{ Government Term- 1 (1991 to 1996) } \\
\hline \multicolumn{1}{|c|}{ Particulars } & March 20, 1991 & March 19, 1996 & Change in \% \\
\hline Turnover Value Tk. in Million & 0.37 & 29.50 & $7,855.91$ \\
\hline Market Capitalization Tk. in Million & $11,904.48$ & $52,442.35$ & 340.53 \\
\hline DSE All Share Price Index (DSI) in Points & 351.00 & 830.69 & 136.66 \\
\hline Initial Public Offerings Nos. & & 67.00 & \\
\hline Market cap to GDP ratio in Percentage & 0.88 & 3.15 & 258.31 \\
\hline Turnover ratio in Percentage & 0.003 & 0.056 & $1,706.00$ \\
\hline Average Daily Value Traded Tk. Million & 0.54 & 9.46 & $1,656.97$ \\
\hline
\end{tabular}

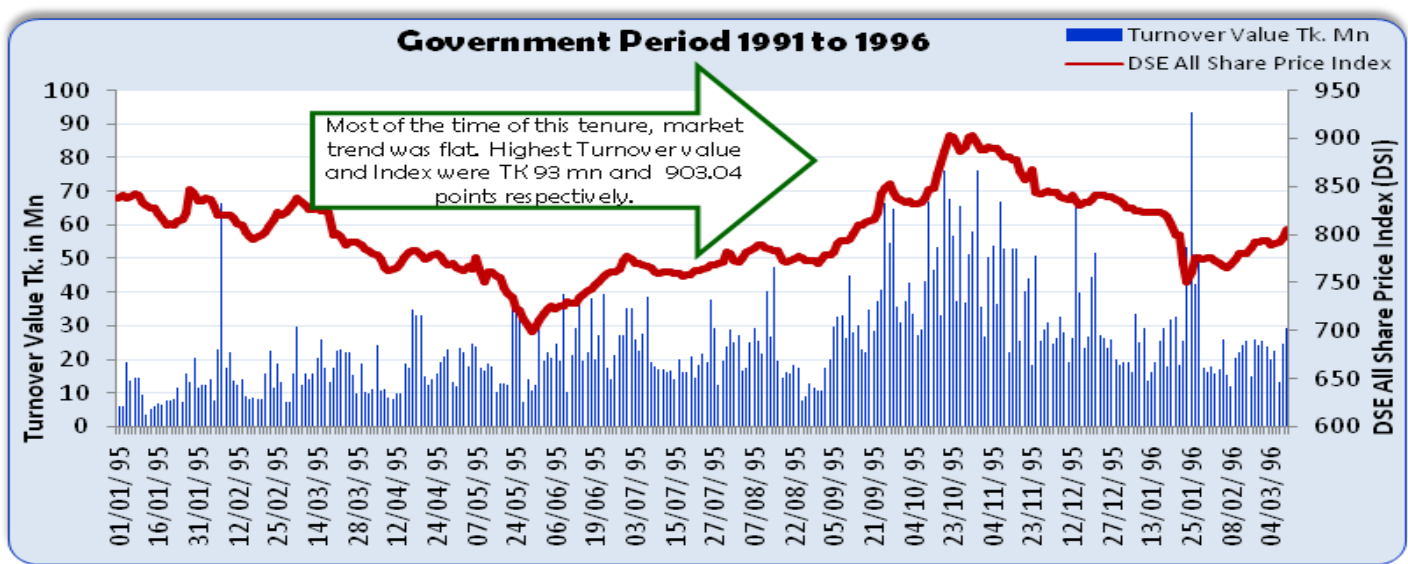

Chart 1. Government Period 1991 to 1996 


\section{Government Term 2 (1996 to 2001)}

Descriptive Observations: In table 3; on June 23, 1996 the turnover value was Tk. 90.65 million, which stood at Tk. 120.10 million on July 15, 2001 representing 32 percent growth. The Market Capitalization was Tk. 66.28 billion on June 23, 1996, which reached at Tk. 70.28 billion on July 15, 2001, registering 6 percent growth. DSI Index was 976.20 points on June 23, 1996, which decreased to 707.77 points on July 15, 2001 witness 28 percent down. The average daily value traded was Tk. 132.44 million during this period which was Tk. 9.46 million in previous government term demonstrates 1300 percent appreciation. Market Capitalization to GDP decreased from 3.99 percent to 2.57 percent during the tenure. At the beginning of the term, the turnover ratio was 0.14 percent, that increased by 25 percent to 0.17 percent. During the tenure, a total 61 firms have off-loaded shares in the capital market.

Table 3. Government Term-2 (1996 to 2001)

\begin{tabular}{|l|r|r|r|}
\hline \multicolumn{4}{|c|}{ Government Term- 2 (1996 to 2001) } \\
\hline \multicolumn{1}{|c|}{ Particulars } & June 23, 1996 & July 15, 2001 & Change in \%o \\
\hline Turnover Value Tk. in Million & 90.65 & 120.10 & 32.49 \\
\hline Market Capitalization Tk. in Million & $66,283.82$ & $70,282.93$ & 6.03 \\
\hline DSE All Share Price Index (DSI) in Points & 976.20 & 707.77 & $(27.50)$ \\
\hline Initial Public Offerings Nos. & & 61.00 & \\
\hline Market cap to GDP ratio in Percentage & 3.99 & 2.57 & $(35.59)$ \\
\hline Turnover ratio in Percentage & 0.137 & 0.171 & 24.95 \\
\hline Average Daily Value Traded Tk. Million & 9.46 & 132.44 & $1,300.00$ \\
\hline
\end{tabular}

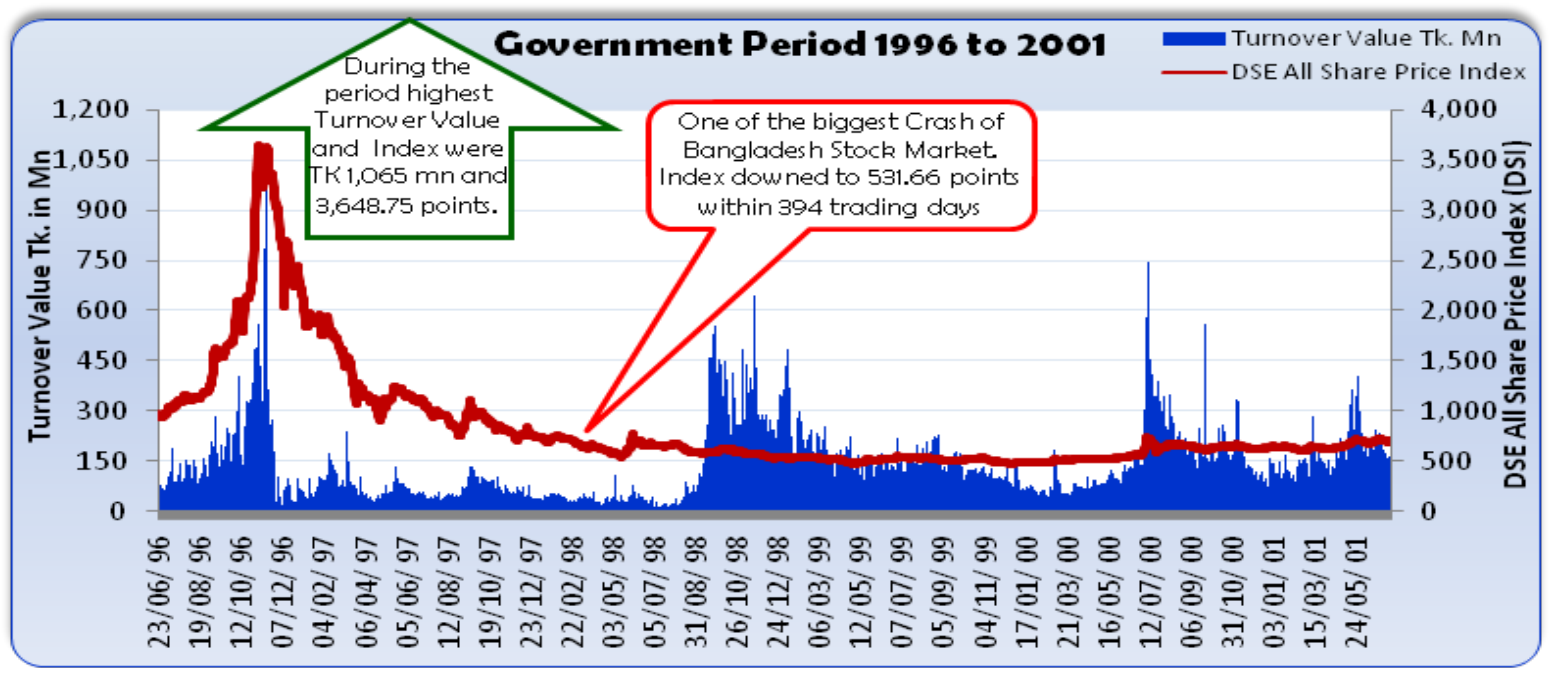

Chart 2. Government Period 1996 to 2001

Table 4. Government Term-3 (2001 to 2006)

\begin{tabular}{|l|r|r|r|}
\hline \multicolumn{4}{|c|}{ Government Term- 3 (2001 to 2006) } \\
\hline \multicolumn{1}{|c|}{ Particulars } & October 10, 2001 & October 22, 2006 & Change in \% \\
\hline Turnover Value Tk. in Million & 257.85 & 215.48 & $(16.43)$ \\
\hline Market Capitalization Tk. in Million & $70,339.88$ & $282,123.48$ & 301.09 \\
\hline DSE General Index (DGEN) in Points & 702.30 & $1,542.44$ & 119.63 \\
\hline Initial Public Offerings Nos. & & 45.00 & \\
\hline Market cap to GDP ratio in Percentage & 2.57 & 5.97 & 132.30 \\
\hline Turnover ratio in Percentage & 0.367 & 0.076 & $(79.16)$ \\
\hline Average Daily Value Traded Tk. Million & 132.44 & 170.63 & 28.84 \\
\hline
\end{tabular}




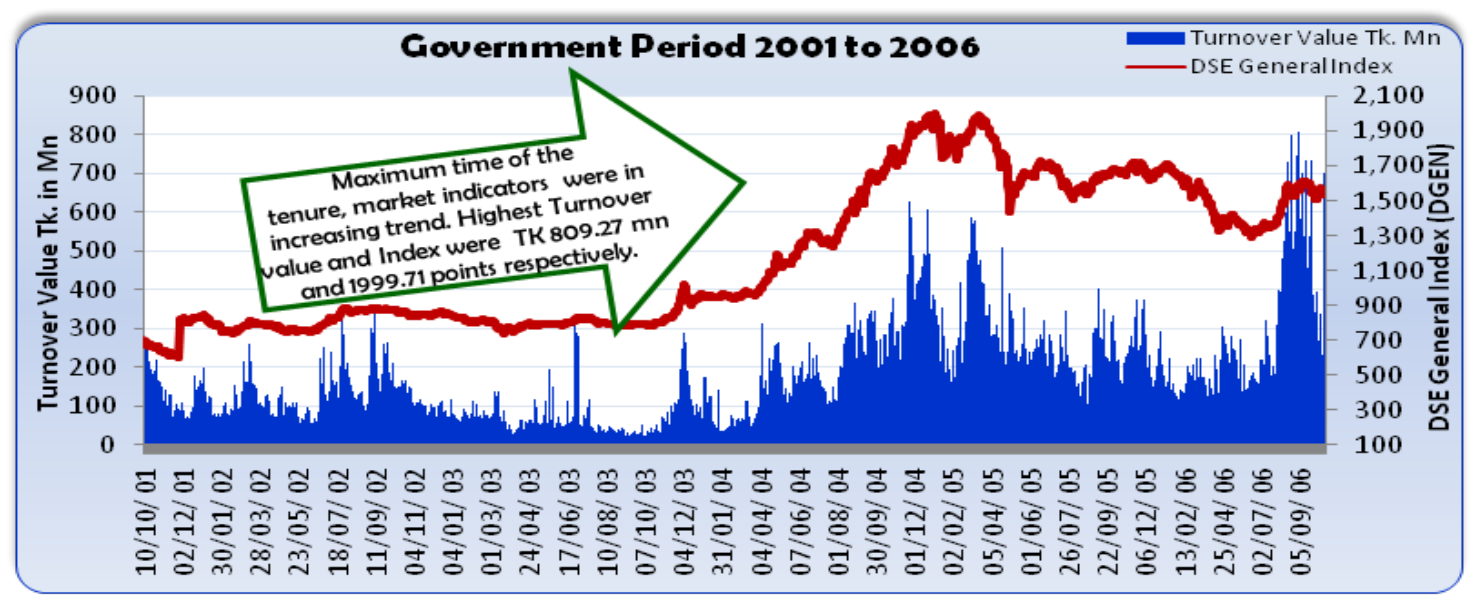

Chart 3. Government Period 2001 to 2006

Chart 2 shows the daily DSI index and turnover value. The highest turnover value and DSI Index were Tk. 1065.04 million and 3648.75 points during this term.

Statistical Analysis: In table 7, total 1344 observations have been used for government term 2. The mean and median return were $(0.002)$ and $(0.022)$ percent respectively where the Standard deviation was 2.13 percent.

\section{Government Term 3 (2001 to 2006)}

Descriptive Observations: In table 4; on October 10, 2001, the turnover value was Tk. 257.85 million, which stood at Tk. 215.48 million on October 22, 2006 representing 16 percent negative growth. The Market Capitalization was Tk. 70.34 billion on October 10, 2001, which reached at Tk. 282.12 billion on October 22, 2006, registering 301 percent growth. DGEN Index was 702.30 points on October 10, 2001, which increased to $1,542.44$ points on October 22, 2006 confirming 120 percent up. The average daily value traded was Tk. 170.63 million during this period which was Tk. 132.44 million in previous government term demonstrates 28.84 percent appreciation. Market Capitalization to GDP decreased from 2.57 percent to 5.97 percent during the tenure. At the beginning of the term, the turnover ratio was 0.367 percent, that decreased by 79.16 percent to 0.076 percent. During the period, a total 45 firms have off-loaded shares in the capital market.

Chart 3 shows the daily DGEN index and turnover value.
The highest turnover value and DGEN Index were Tk. 809.27 million and 1,999.71 points during this term.

Statistical Analysis: In table 7, total 1350 observations have been used for government term 3. The mean and median returns were 0.067 and 0.01 percent respectively where the Standard deviation and CV were 1.35 percent and 20.28 respectively.

\section{Government Term 4 (2006 to 2009)}

Descriptive Observations: In table 5, on October 31, 2006, the turnover value was Tk. 261.21 million, which stood at Tk. 4,642.24 million on January 05, 2009, representing 1,677 percent huge growth. The Market Capitalization was Tk. 281.40 billion on October 31, 2006, which reached at Tk. 1,057.95 billion on January 05, 2009, registering 276 percent growth. DGEN Index was $1,541.65$ points on October 31,2006 , which increased to $2,808.45$ points on January 05,2009 confirming 82 percent up. The average daily value traded was Tk. 1,978.80 million during this period which was Tk. 170.63 million in previous government term demonstrates 1,060 percent appreciation. Market Capitalization to GDP decreased from 5.96 percent to 15.24 percent during the tenure. At the beginning of the term, the turnover ratio was 0.093 percent, that increased by 372.71 percent to 0.439 percent. During the tenure, a total 28 firms have off-loaded shares in the capital market.

Table 5. Government Term-4 (2006 to 2009)

\begin{tabular}{|c|c|c|c|}
\hline \multicolumn{4}{|c|}{ Government Term- 4 (2006 to 2009) } \\
\hline Particulars & October 31, 2006 & January 5, 2009 & Change in \% \\
\hline Turnover Value Tk. in Million & 261.21 & $4,642.24$ & $1,677.21$ \\
\hline Market Capitalization Tk. in Million & $281,397.10$ & $1,057,947.03$ & 275.96 \\
\hline DSE General Index (DGEN) in Points & $1,541.65$ & $2,808.45$ & 82.17 \\
\hline Initial Public Offerings Nos. & & 28.00 & \\
\hline Market cap to GDP ratio in Percentage & 5.96 & 15.24 & 155.70 \\
\hline Turnover ratio in Percentage & 0.093 & 0.439 & 372.71 \\
\hline Average Daily Value Traded Tk. Million & 170.63 & $1,978.80$ & $1,059.69$ \\
\hline
\end{tabular}




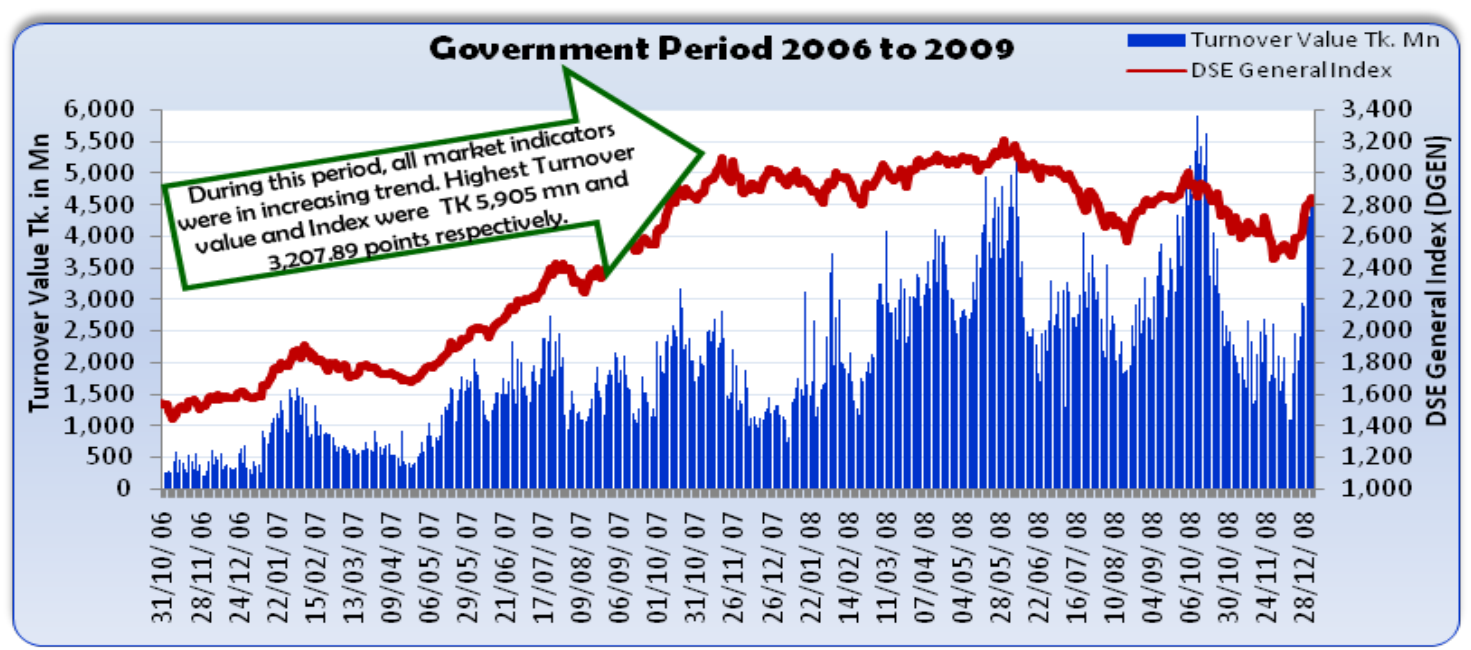

Chart 4. Government Period (2006 to 2009)

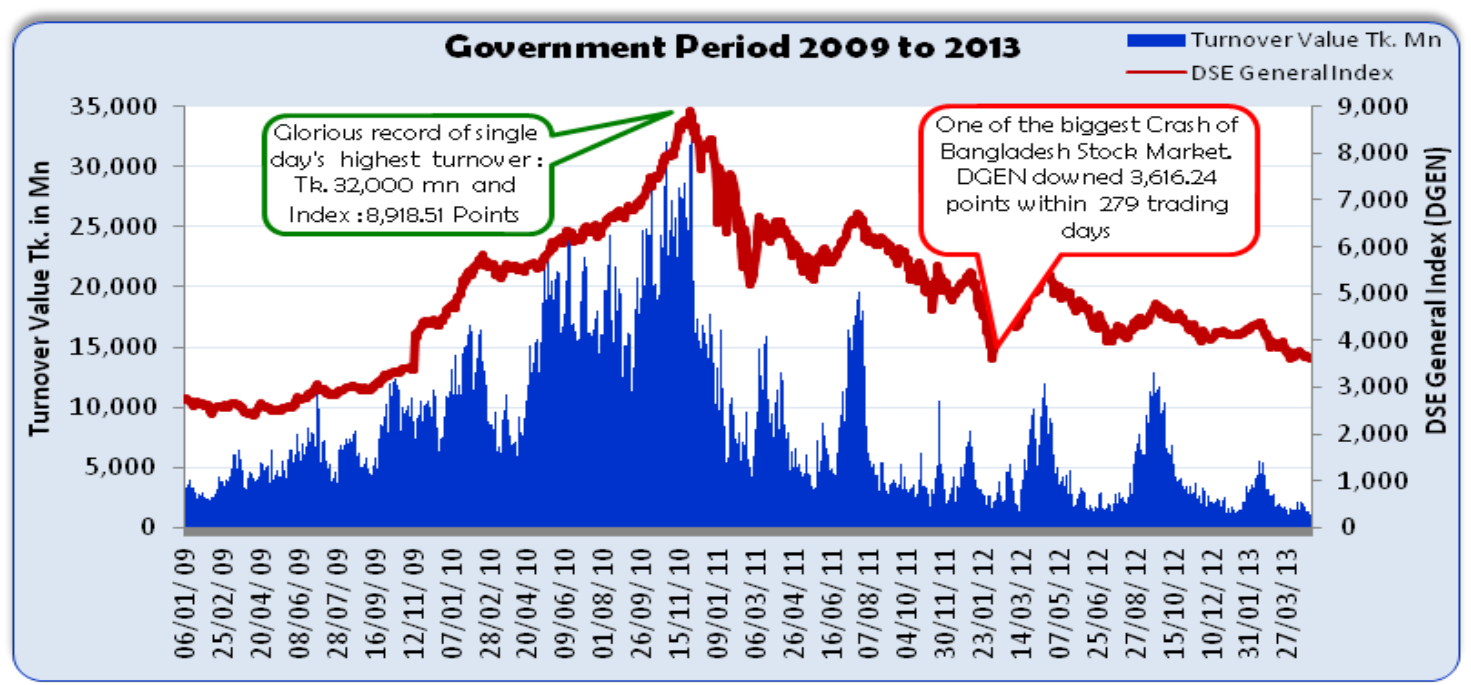

Chart 5. Government Period (2009 to 2013)

Table 6. Government Term-5(2009 to 2013)

\begin{tabular}{|l|r|r|r|}
\hline \multicolumn{4}{|c|}{ Government Term- 5 (2009 to 2013) } \\
\hline \multicolumn{1}{|c|}{ Particulars } & January 6, 2009 & April 30, 2013 & Change in \% \\
\hline Turnover Value Tk. in Million & $3,788.71$ & $1,364.33$ & $(63.99)$ \\
\hline Market Capitalization Tk. in Million & $1,042,968.82$ & $2,166,577.33$ & 107.73 \\
\hline DSE General Index (DGEN) in Points & $2,756.66$ & $3,618.49$ & 31.26 \\
\hline Initial Public Offerings Nos. & & 70.00 & \\
\hline Market cap to GDP ratio in Percentage & 15.02 & 23.68 & 57.66 \\
\hline Turnover ratio in Percentage & 0.363 & 0.063 & $(82.67)$ \\
\hline Average Daily Value Traded Tk. Million & $1,978.80$ & $7,906.66$ & 299.57 \\
\hline
\end{tabular}


Table 7. Descriptive Statistics Findings

\begin{tabular}{|c|c|c|c|c|c|}
\hline \multicolumn{6}{|c|}{ Descriptive Statistics Findings } \\
\hline \multirow{2}{*}{ Statistical Findings } & Term 1 & Term 2 & Term 3 & Term 4 & Term 5 \\
\hline & 1991-1996 & 1996-2001 & $2001-2006$ & $2006-2009$ & $2009-2013$ \\
\hline Mean & 0.00075 & $(0.00002)$ & 0.00067 & 0.00125 & 0.00047 \\
\hline Median & 0.00014 & $(0.00022)$ & 0.00012 & 0.00140 & 0.00045 \\
\hline Standard Deviation & 0.01628 & 0.02126 & 0.01352 & 0.01284 & 0.02058 \\
\hline Coefficient of Variation (CV) & 21.5930 & & 20.2833 & 10.2752 & 43.7875 \\
\hline Kurtosis & 196.3268 & 43.9968 & 292.5431 & 0.6639 & 18.9264 \\
\hline Skewness & 1.7979 & 1.7536 & 11.5671 & 0.1083 & 1.5256 \\
\hline Minimum & $(0.25079)$ & $(0.22204)$ & $(0.07095)$ & $(0.03921)$ & $(0.08908)$ \\
\hline Maximum & 0.33098 & 0.30366 & 0.33930 & 0.04737 & 0.22608 \\
\hline Number of Observations & 1,337 & 1,344 & 1,350 & 514 & 1,038 \\
\hline
\end{tabular}

Chart 4 shows the daily DGEN index and turnover value. The highest turnover value and DGEN Index were Tk. 5,905.15 million and 3207.89 points during this term.

Statistical Analysis: In table 7, total 514 observations have been used for government term 4. The mean and median returns were 0.125 and 0.140 percent respectively where the Standard deviation and CV were 1.28 percent and 10.28 respectively

\section{Government Term 5 (2009 to 2013)}

Descriptive Observations: In table 6; on January 06, 2009 the turnover value was Tk. 3,788 million, which stood at Tk. 1,364 million on April 30, 2013 representing 64 percent negative growth. The Market Capitalization was Tk. 1,042.97 billion on January 06, 2009, which reached at Tk. 2,166.58 billion on April 30, 2013 registering 108 percent growth. DGEN Index was $2,756.66$ points on January 06 , 2009 which increased to 3,618.49 points on April 30, 2013 confirming 31 percent up. The average daily value traded was Tk. 7,906.66 million during this period which was Tk. 1978.80 million in previous government term demonstrates 300 percent appreciation. Market Capitalization to GDP increased from 15.02 percent to 23.68 percent during the tenure. At the beginning of the term, the turnover ratio was 0.363 percent, that decreased by 82.67 percent to 0.063 percent. During the term, a total 70 firms have off-loaded shares in the capital market.

Chart 5 shows the daily DGEN index and turnover value. The Glorious record of single day's highest turnover value was Tk. 32,000 million and DSE General Index reached its highest level at 8,991 points on December 05, 2010.

Statistical Analysis: In table 7, total of 1038 observations have been used for government term 5 . The mean and median returns were 0.047 and 0.045 percent respectively where the Standard deviation and CV were 2.058 percent and 43.79 respectively

\section{Major Findings: - a comparative analysis}

From the above analyses and table 7, we observe that the government term 4 has the highest mean and median return $(0.125 \% \& 0.140 \%)$ where the term 2 has lowest mean and median return (Negative). On the other hand, although the term 4 has highest mean return, its volatility or risk was lowest among all the government terms as its standard deviation is only 1.28 percent which is lowest. The term 4 has also the lowest coefficient of variation $(\mathrm{CV})$ which measures the risk per unit of return is 10.28. But, even though the government term 2 has negative return, it has highest volatility or risk as its standard deviation is 2.13 percent, which is largest.

Apart from government term 2, the current term 5 has the highest volatility with comparatively lower mean return. In contrast, the government term 1 and 3 have almost similar and consistent risk-return pattern as their $\mathrm{CV}$ were 21.59 and 20.28 respectively. And surprisingly, these two terms $(1 \& 3)$ were led by the same political party; BNP.

If we further examine the descriptive observations and table- 2 to 6 , we also found that all the market indicators have comparatively very significant positive growth under government term 1 and 4 while the government terms 2 and 5 have very poor or negative growth in terms of most of the indicators.

Another important thing to be noted that the two big crashes (1996 \& 2011) occurred during the government terms 2 and 5 respectively which are depicted in chart 2 and 5 . The market performance under these two government terms was also worse than that of rest of the terms. And coincidentally, the same political party; Bangladesh Awami League has been at government during these two terms. Thus, it is evident from the above analysis that the political parties holding power in government had significant impact on the stock market performance as the political parties at government changes; the market performance also changes significantly.

Khondoker Ibrahim Khaled's probe report on stock market crash in 2011 found that market got imbalanced during the Caretaker government in 2007 which ultimately translated into a market crash in 2011 during the AL regime. However, why the market performance during AL regime is not good comparing to during BNP's leadership is an area of further research. 


\section{Conclusion}

From our analysis it is evident that the performance of stock market was better during non-political government (caretaker) in 2006 to 2009 in all aspects. Under this period, the average market return was highest while volatility was lowest and all other market indicators had shown significant growth. However, if we consider only political governments, the performance of stock market was best during BNP led government in 1991 to 1996 in all aspects. During this period, the average market return was highest while volatility was low and all other market indicators had shown significant growth. On contrary, the performance of stock market was very poor during Awami league regime in 1996 to 2001 in all aspects. During this period, the average market return was negative while volatility was highest. Even during the current Awami league administration, market experiences very low average return combined with high volatility. However, in both terms of BNP led government, i.e., 1991 to 1996 and 2001 to 2006, market experienced comparatively consistent return-volatility relation.

To that end, we may conclude that the market performed best under the non-political government (caretaker) during 2006-2009 while market performed worse under Awami league led government during 1996-2001 \& 2009-2013. However, the market performance was well and consistent under BNP led government during 1991-1996 \& 2001-2006. Therefore, from the above analysis it is evident that the political parties holding power in government had significant influence on stock market performance.

Even though Ibrahim Khaled's probe report on stock market crash in 2011 has given some comfort to Awami League that the market got imbalanced or bubble during earlier government in 2007 which translated into a crash in their term in 2011, Awami League government cannot ignore the liability for repeated market crashes (1996 \& 2011). However, why market got into crash repeatedly during Awami League regime, why the market performance during AL regime is not good comparing to during BNP's leadership is an area of further research.

\section{REFERENCES}

[1] Ansolabehere, Stephen, John M. De Figueiredo and James M. Snyder Jr. (2003). Why is there so Little Money in U.S. Politics? Journal of Economic Perspectives, 17(1), 105-130.

[2] Beyer, S. B., Jensen, G. R., \& Johnson, R. R. (2004). Don't worry about the election, just watch the Fed. The Journal of Portfolio Management, Summer 2004, 101-108.

[3] Bijon B. Sarma (2012). Election and Democracy in Bangladesh, the Unknown Riddle and Proposal for Improvement. File retrieved from:

[4] http://www.priyoaustralia.com.au/articles/138846-election-a nd-democracy-in-bangladesh-the-unknown-riddle-and-propo sal-for-improvement.html.

[5] Chowdhury, A.R. (1994). Statistical Properties of Daily Returns from Dhaka Stock Exchange, The Bangladesh Development Studies, 26(4), 61-76.

[6] Jedrzej B., Katrin G. and Tomasz P. W. (2006). Political Orientation of Government and Stock Market Returns, Working Paper. File retrieved from:

[7] https://www.econstor.eu/dspace/bitstream/10419/22113/1/p9 2006.pdf

[8] Nikhar Gaikwad (2013). Presidential Prospects, Political Connections, and Stock Market Performance. File retrieved from: www.yale.edu/csap/seminars/gaikwad.pdf.

[9] Oumar Sy and Ashraf Al Z. (2011). Resolving the Presidential Puzzle, Financial Management, 40(2), 331-355.

[10] Ray M. V. and Marshall D. N. (2012). The U.S. Presidency and the Stock Market: A political relationship study of the market performance, Research in Business and Economics Journal. File retrieved from: http://www.aabri.com/manuscripts/121230.pdf.

[11] Roland F. and Michael M. B. (2007). Partisan Politics and Stock Market Performance: The Effect of Expected Government Partisanship on Stock Returns in the 2002 German Federal Election, Social Science Research Network, Public Choice 135(3-4), 131-150.

[12] Santa-Clara, P. \& Valkanov, R. (2003). The presidential puzzle: Political cycles and the stock market, The Journal of Finance, LVIII (5), 1841-1872.

[13] Share Market Inquiry Report, (2011). The committee is headed by Khondkar Ibrahim Khaled. Retrieved from http://www.mof.gov.bd/en/budget/share/report.pdf. 